\title{
PERTUMBUHAN Euphorbia pulcherrima AKIBAT BENTUK PEMOTONGAN STEK DAN KONSENTRASI AUKSIN
}

\author{
Oleh : \\ Aghnia Rahmawati*) \\ Ai Komariah**) \\ Hudaya Mulyana**)
}

\begin{abstract}
Abstrak
Penelitian ini bertujuan untuk mendeskripsikan pertumbuhan Kastuba akibat bentuk pemotongan stek dan konsentrasi auksin. Selain itu, penelitian ini juga bertujuan untuk mengungkap konsentrasi auksin optimum yang dapat meningkatkan pertumbuhan Kastuba. Penelitian ini merupakan penelitian dengan pendekatan eksperimen di lahan percobaan. Percobaan dilaksanakan di lahan milik Petani Di Desa Cihideung Kecamatan Parongpong Kabupaten Bandung Barat. Pendekatan eksperimen ini menggunakan rancangan percobaan Rancangan Acak Kelompok (RAK) Faktorial diulang tiga kali. Tidak terdapat interaksi antara bentuk pemotongan stek bentuk $\mathrm{v}$ dan miring dengan konsentrasi auksin terhadap pertumbuhan tanaman kastuba yakni terhadap jumlah daun, luas daun, jumlah cabang, volume akar, panjang akar, jumlah akar, dan bobot kering. Bentuk pemotongan stek dengan bentuk v meningkatkan jumlah daun, jumlah cabang, dan volume akar pada umur 40 hst. Konsentrasi auksin $0,3 \mathrm{~g} \mathrm{~L}^{-1}$ memberikan hasil tertinggi pada aspek pertumbuhan luas daun, jumlah cabang, volume akar, dan jumlah akar. Tidak terdapat model kuadratik yang sesuai sehingga konsentrasi auksin yang optimum tidak dapat ditentukan. Konsentrasi auksin 0,3 g $\mathrm{L}^{-1}$ memberikan hasil tertinggi pada aspek pertumbuhan jumlah akar. Konsentrasi Auksin 0,1 g $\mathrm{L}^{-1}$ dapat diusahakan untuk mendapatkan pertumbuhan kastuba yang lebih baik dengan bentuk pemotongan stek bentuk pemotongan stek miring $45^{\circ}$ dan bentuk " $v$ " di Kecamatan Parongpong. Konsentrasi Auksin 0,3 g $\mathrm{L}^{-1}$ dapat diusahakan untuk mendapatkan pertumbuhan kastuba yang lebih baik dengan bentuk pemotongan stek bentuk pemotongan stek miring $45^{\circ}$ dan bentuk " $v$ " di Kecamatan Parongpong.
\end{abstract}

Kata Kunci : Kastuba, Bentuk Stek, Auksin, Pertumbuhan'Program Studi Agroteknologi,

\begin{abstract}
Abstrac
This study aims to describe the growth of Christmas Flower due to the form of cutting and auksin concentration. In addition, this study also aims to reveal the optimum auksin concentration that can enhance the growth of Christmas Flower. This research is a research with experimental approach in experimental field. The experiment was conducted on farmer's land in Cibideung Village, Parongpong District, West Bandung Regency. This experimental approach using the Factorial Randomized Block Design ( $\mathrm{R} A K)$ design was repeated three times. There is no interaction between the form of cutting of v-shaped cuttings and tilting with auksin concentration on the growth of Christmas Flower plants on the number of leaves, leaf area, number of branches, root volume, root length, root number, and dry weight. The form of cuttings with v-shapes increases the number of leaves, number of branches, and root volume at 40 hst. Concentrations of auxin $0.1 \mathrm{~g} \mathrm{~L}$ 1, $0.2 \mathrm{~g} \mathrm{L-1}$, and $0.3 \mathrm{~g} \mathrm{L-1}$ gave the bighest yield on some aspects of growth. There is no suitable quadratic model so that the optimum concentration of auxin can not be determined. Auxin
\end{abstract}


concentration of $0.1 \mathrm{~g} \mathrm{~L}-1$ can be attempted to obtain better caster growth by cutting the cutting method of cutting slant $45^{\circ}$ and " $v$ " in Parongong District.

Keywords: Auxin, Chirstmas Flower, Cutting Form, Growth.

*)Fakultas Pertanian, Universitas Bandung Raya, Jl. Banten No 11, Bandung 40272, Indonesia

**)Program Studi Agroteknologi, Fakultas Pertanian, Universitas Winayamukti,jl. Raya Bandung Sumedang No. 29, Sumedang 45362, Indonesia 


\section{PENDAHULUAN}

\section{Euphorbia pulcherima (Kastuba)} termasuk tanaman hias yang digemari. Bagian yang berwarna merah, pink, atau putih dari tanaman kastuba merupakan daun yang telah mengalami modifikasi atau biasa disebut braktea. Selain braktea tersebut, adanya sel yang dapat menghasilkan lateks merupakan ciri khusus dari tanaman kastuba. Braktea kastuba yang berwarna warni, jumlahnya yang beragam, dan bentuk yang menarik meningkatkan nilai jual kastuba.

Kastuba juga merupakan komoditas hortikultura yang cukup bernilai ekonomi tinggi dan banyak diminati konsumen serta dapat dibudidayakan secara komersial (Olberg, 2016). Nilai ekonomi yang tinggi disebabkan karena kastuba merupakan tanaman musiman atau "seasonal" yang hanya diproduksi pada periode tertentu setiap tahunnya (Siska, dkk., 2015).

Saat ini, di Indonesia permintaan kastuba cukup tinggi pada perayaan harihari tertentu seperti menjelang lebaran, perayaan natal, hari kemerdekaan RI, dan tahun baru. Di Jawa Barat, produksi tanaman kastuba dapat mencapai \pm 1.200.000 pot/tahun.

Kecamatan

Parongpong Kabupaten Bandung Barat adalah salah satu wilayah diproduksinya tanaman kastuba. Di Kecamatan Parongpong, kastuba dapat diproduksi \pm 50.000 pot/tahun. Umumnya, tanaman ini diproduksi dan ditanam sebagai tanaman hias di pekarangan, pelengkap dekorasi acara tertentu, hiasan meja, hiasan di pinggir jalan, dan di taman-taman.

Tanaman Kastuba biasanya ditanam di pot atau di polibag. Perawatan kastuba dalam pot atau polibag tergolong mudah, yang terpenting jangan terlalu banyak disiram. Penyiraman cukup 2 hari sekali. Jika sudah satu bulan dipelihara, media tanamnya harus segera diganti dan diberi pupuk seimbang. Beberapa hal yang wajib diperhatikan dalam memilih kastuba adalah ukuran daun yang proposional, warnanya yang terang, rumpun berwarna hijau dalam jumlah yang cukup banyak.
Umumnya, kastuba dibudidayakan dengan cara stek (Chairur, 2016). Cara ini adalah cara pembudidayaan tanaman kastuba yang cukup sederhana dan cepat namun tetap menghasilkan tunas keturunan yang sama dengan induknya. Selain itu, dengan cara stek tidak menggunakan teknik-teknik tertentu yang sulit atau khusus dalam pengaplikasiannya (Purnamasari, 2014).

Di lapangan, khusunya di Kecamatan Parongpong tanaman kastuba banyak dibudidayakan dengan cara stek pucuk. Tanaman kastuba yang dibudidayakan dengan stek pucuk, bahan stek nya dapat dipotong secara mendatar, bentuk "v" dan miring 450. Model pemotongan stek tersebut mempengaruhi penyerapan nutrisi yang diperlukan oleh tanaman (Mashudi, 2015). Besarnya luas permukaan pada bahan stek yang telah dipotong memungkinkan penyerapan nutrisi yang lebih banyak.

Kenyataan di lapangan, sistem perbanyakan stek pucuk pada kastuba ditemukan beberapa kendala, diantaranya yaitu pemilihan tanaman yang harus berkualitas dan faktor luar termasuk di dalamnya media tanam, suhu, kelembaban, serta perlakuan zat kimia atau zat pengatur tumbuh yang tidak optimum. Selain itu, kenyataan di lapangan ditemukan bahwa lamanya muncul perakaran pada tanaman kastuba menjadi sebuah kendala dalam budidaya tanaman kastuba, yakni sekitar 1-2 bulan.

Usaha yang dapat dilakukan dalam pembiakan kastuba dengan kendala tersebut, pada umumnya menggunakan hormon atau zat pengatur tumbuh kelompok auksin (Suprapto, 2004). Hal tersebut dilakukan dalam upaya menumbuhkan akar dan pemanjangan tunas. Auksin merupakan faktor yang mempengaruhi tanaman dari faktor luar.

Tanpa hormon perangsang akarpun sebenarnya masih bisa ,mengeluarkan akar (Astuti dan Agung, 2008). Namun, kemungkinan kecil, terutama pada kultivar tertentu yang tergolong sulit berakar. Selain itu, akar yang dihasilkan tidak seragam. 
Berdasarkan hal tersebut di atas, dapat digambarkan bahwa auksin merupakan salah satu hormon atau zat pengatur tumbuh yang tepat untuk membantu pertumbuhan akar. Selain itu, bentuk pemotongan stek yang baik juga termasuk faktor luar yang dapat mempengaruhi pertumbuhan kastuba. Maka dari itu, perlu dilakukan penelitian tentang pertumbuhan tanaman kastuba akibat bentuk pemotongan stek dan pemberian berbagai konsentrasi auksin.

\section{MATERIAL DAN METODE}

Penelitian ini bertujuan untuk mempelajari tentang pertumbuhan Euphorbia pulcherrima (Kastuba) akibat bentuk pemotongan stek dan beberapa konsentrasi auksin, maka penelitian ini merupakan penelitian dengan pendekatan eksperimen di lahan percobaan.

Percobaan dilaksanakan di lahan milik Petani Di Desa Cihideung Kecamatan Parongpong Kabupaten Bandung Barat. Desa Cihideung terletak pada $06^{0} 41^{\prime}$ - $07^{0} 19^{\prime}$ Lintang Selatan dan $107^{0}$ 22' - $108^{0}$ 05' Bujur Timur. Ketinggian tempat $1.100 \mathrm{~m}$ di atas permukaan laut. Percobaan dilakukan pada bulan Juli sampai dengan bulan September 2017.

Bahan yang digunakan dalam percobaan meliputi benih stek pucuk dengan tinggi $\pm 10 \mathrm{~cm}$ dan berdaun 5 dari tanaman Kastuba, 10 \% IAA (Merk dagang: Sun Plus), sekam bakar, oasis, pupuk NPK, dan Antracol.

Alat-alat yang digunakan dalam percobaan ini adalah polibag $8 \mathrm{~cm} \times 9 \mathrm{~cm}$, sekop, sprayer, penggaris, cutter, ember, timbangan, gelas ukur, kertas label, dan alat tulis untuk pengamatan.

Pendekatan eksperimen ini menggunakan rancangan percobaan Rancangan Acak Kelompok (RAK) Faktorial diulang tiga kali. Tiap perlakuan dalam tiap ulangan terdiri atas 10 tanaman Euphorbia pulcherima (Kastuba) yang ditanam dalam polibag (10 polibag dalam 1 petak perlakuan, terdapat 120 bahan stek dalam 1x ulangan). Jarak antar perlakuan 0,5 $\mathrm{m}$ dan jarak antar ulangan $1,0 \mathrm{~m}$.

\section{HASIL DAN PEMBAHASAN}

Hasil Pengamatan menunjukkan bahwa tanaman kastuba yang diberi perlakuan berbeda menunjukkan pertumbuhan yang bermacam-macam. Pada perlakuan bentuk pemotongan stek $\mathrm{v}$ dan konsentrasi auksin $0 \mathrm{~g} \mathrm{~L}^{-1}$ terdapat $24(80 \%)$ tanaman yang tumbuh setelah tanam. Pada perlakuan bentuk pemotongan stek $\mathrm{V}$ dan konsentrasi auksin 0,1 g $\mathrm{L}^{-1}$ terdapat $27 \quad(90 \quad \%)$ tanaman yang tumbuh setelah tanam. Pada perlakuan bentuk pemotongan stek $\mathrm{v}$ dan konsentrasi auksin 0,2 $\mathrm{g} \mathrm{L}^{-1}$ terdapat $24(80 \%)$ tanaman yang tumbuh setelah tanam. Pada perlakuan bentuk pemotongan stek $\mathrm{V}$ dan konsentrasi auksin 0,3 g $\mathrm{L}^{-1}$ terdapat $27 \quad(90 \%)$ tanaman yang tumbuh setelah tanam. Pada perlakuan bentuk pemotongan stek $\mathrm{v}$ dan konsentrasi auksin $0,4 \mathrm{~g} \mathrm{~L}^{-1}$ terdapat $21(70 \%)$ tanaman yang tumbuh setelah tanam. Pada perlakuan bentuk pemotongan stek $\mathrm{V}$ dan konsentrasi auksin 0,5 g $\mathrm{L}^{-1}$ terdapat $21 \quad(70 \%)$ tanaman yang tumbuh setelah tanam.

Pada perlakuan bentuk pemotongan stek miring dan konsentrasi auksin $0 \mathrm{~g} \mathrm{~L}^{-1}$ terdapat $21(70 \%)$ tanaman yang tumbuh setelah tanam. Pada perlakuan bentuk pemotongan stek miring dan konsentrasi auksin $0,1 \mathrm{~g} \mathrm{~L}^{-1}$ terdapat $24(80 \%)$ tanaman yang tumbuh setelah tanam. Pada perlakuan bentuk pemotongan stek miring dan konsentrasi auksin 0,2 $\mathrm{g} \mathrm{L}^{-1}$ terdapat $24(80 \%)$ tanaman yang tumbuh setelah tanam. Pada perlakuan bentuk pemotongan stek miring dan konsentrasi auksin 0,3 $\mathrm{g} \mathrm{L}^{-1}$ terdapat $27(90 \%)$ tanaman yang tumbuh setelah tanam. Pada perlakuan bentuk pemotongan stek miring dan konsentrasi auksin $0,4 \mathrm{~g} \mathrm{~L} \mathrm{~L}^{-1}$ terdapat $21 \quad(70 \%)$ tanaman yang tumbuh setelah tanam. Pada perlakuan bentuk pemotongan stek miring dan konsentrasi auksin 0,5 $\mathrm{g} \mathrm{L}^{-1}$ terdapat $21(70 \%)$ tanaman yang tumbuh setelah tanam. 
Suhu udara rata-rata yang terdapat di tempat percobaan adalah $21^{\circ} \mathrm{C}$. Suhu tersebut cocok dan sesuai dengan syarat tumbuh dari tanaman kastuba. Curah hujan rata-rata di daerah penelitian adalah 2000-2500 mm/tahun. Pada penelitian ini, di lapangan ditemukan hama kutu putih atau Whiteflies (Trialeurodes vaporariorum). Selain hama, terdapat pula penyakit yang menyerang kastuba. Dengan gejala yang sama, peneliti menyebutkan bahwa penyakit yang menyerang pada tanaman kastuba adalah penyakit bercak daun bakteri. Penyakit bercak daun bakteri disebabkan oleh bakteri Xanthomonas poinsettiaecola. Penyakit ini menyebabkan daun berubah warna menjadi kuning dan gugur lebih awal. Selain itu, terdapat penyakit kanker bakteri yang disebabkan oleh bakteri Comyebacterium poinsettia.

Pada penelitian ini tidak terjadi interaksi antara bentuk pemotongan stek dengan konsentrasi auksin. Masingmasing faktor tersebut tidak saling mepengaruhi terhadap variabel yang diamati yakni terhadap jumlah daun, luas daun, jumlah cabang, volume akar, panjang akar, jumlah akar, dan bobot kering. Hal tersebut dapat disebabkan oleh peran auksin pada berbagai aspek pertumbuhan dan perkembangan tanaman antara lain dalam pembesaran sel, penghambatan mata tunas samping, pengguguran daun, dan pertumbuhan akar dibutuhkan dalam jumlah sedikit (Suprapto, 2014).

\section{Jumlah Daun}

Tabel 1. Jumlah Daun per Tanaman pada Dua Bentuk Stek akibat Konsentrasi Auksin pada Umur 20, hst, 40 hst, dan 60 hst

\begin{tabular}{|c|c|c|c|}
\hline \multirow{2}{*}{ Perlakuan } & \multicolumn{3}{|c|}{ Jumlah Daun per tanaman pada umur } \\
\hline & 20 hst & 40 hst & 60 hst \\
\hline Bentuk Pemotongan (B) & & ....helai.... & 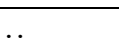 \\
\hline $\mathrm{b}_{1}$ : bentuk pemotongan miring & $1.39 \mathrm{a}$ & $3.56 \mathrm{a}$ & 8.83 a \\
\hline $\mathrm{b}_{2}$ : bentuk pemotongan " $\mathrm{v} "$ & $1.61 \mathrm{a}$ & $4.67 \mathrm{~b}$ & $9.95 \mathrm{a}$ \\
\hline \multicolumn{4}{|l|}{ Konsentrasi Auksin (A) } \\
\hline $\mathrm{a}_{0}: \quad 0 \mathrm{~g} \mathrm{~L}^{-1}$ & $1.17 \mathrm{ab}$ & $3.50 \mathrm{~b}$ & $7.67 \mathrm{~b}$ \\
\hline $\mathrm{a}_{1}: 0.1 \mathrm{~g} \mathrm{~L}^{-1}$ & $2.00 \mathrm{~b}$ & $6.00 \mathrm{c}$ & $13.17 \mathrm{c}$ \\
\hline $\mathrm{a}_{2}: 0.2 \mathrm{~g} \mathrm{~L}^{-1}$ & $1.83 \mathrm{~b}$ & $5.50 \mathrm{bc}$ & $13.00 \mathrm{c}$ \\
\hline $\mathrm{a}_{3}: 0.3 \mathrm{~g} \mathrm{~L}^{-1}$ & $2.50 \mathrm{~b}$ & $7.00 \mathrm{c}$ & $16.50 \mathrm{c}$ \\
\hline $\mathrm{a}_{4}: 0.4 \mathrm{~g} \mathrm{~L}^{-1}$ & $1.00 \mathrm{ab}$ & $1.50 \mathrm{a}$ & $3.00 \mathrm{a}$ \\
\hline $\mathrm{a}_{5}: 0.5 \mathrm{~g} \mathrm{~L}^{-1}$ & $0.50 \mathrm{a}$ & $1.17 \mathrm{a}$ & $1.67 \mathrm{a}$ \\
\hline
\end{tabular}

Keterangan : Nilai rata-rata yang ditandai dengan huruf yang sama berarti berbeda tidak nyata menurut uji Jarak berganda Duncan taraf nyata $5 \%$.

Pada saat 20 hst, bentuk pemotongan stek yang miring dan bentuk $\mathrm{V}$ tidak berpengaruh nyata terhadap jumlah daun. Konsentrasi auksin $0,1 \mathrm{~g} \mathrm{~L}^{-1}$, 0,2 $\mathrm{g} \mathrm{L}^{-1}, 0,3 \mathrm{~g} \mathrm{~L}^{-1}, 0,4 \mathrm{~g} \mathrm{~L}{ }^{-1}, 0,5 \mathrm{~g} \mathrm{~L}^{-1}$ tidak berpengaruh nyata terhadap jumlah daun atau sama dengan kontrol konsentrasi $0 \mathrm{~g}$ $\mathrm{L}^{-1}$.

Pada saat 40 hst, bentuk pemotongan stek yang miring tidak berpengaruh nyata terhadap jumlah daun tetapi bentuk pemotongan stek bentuk $\mathrm{v}$ berpengaruh nyata terhadap jumlah daun. Hal tersebut menunjukkan bahwa bentuk pemotongan stek bentuk $\mathrm{v}$ dapat meningkatkan jumlah daun. Konsentrasi auksin 0,2 $\mathrm{g} \mathrm{L}^{-1}$, dan $0,3 \mathrm{~g} \mathrm{~L}^{-1}$ berpengaruh nyata positif terhadap jumlah daun yakni konsentrasi tersebut dapat meningkatkan jumlah daun. Konsentrasi $0,5 \mathrm{~g} \mathrm{~L}^{-1}$ dan 0,4 $\mathrm{g} \mathrm{L}^{-1}$ berpengaruh nyata negatif terhadap jumlah daun yakni konsentrasi tersebut dapat menurunkan jumlah daun. Konsentrasi auksin, 0,1 g $\mathrm{L}^{-1}$, tidak berpengaruh nyata terhadap jumlah daun atau sama dengan konsentrasi $0 \mathrm{~g} \mathrm{~L}^{-1}$.

Pada saat 60 hst, bentuk pemotongan stek yang miring dan bentuk $\mathrm{V}$ tidak berpengaruh nyata terhadap jumlah daun. Konsentrasi auksin $0,1 \mathrm{~g} \mathrm{~L}^{-1}$, 0,2 $\mathrm{g} \mathrm{L}^{-1}$, dan $0,3 \mathrm{~g} \mathrm{~L}^{-1}$ berpengaruh nyata positif terhadap jumlah daun yakni konsentrasi tersebut dapat meningkatkan jumlah daun. Konsentrasi auksin 0,5 g L- 
${ }^{1}$ dan $0,4 \mathrm{~g} \mathrm{~L}^{-1}$, berpengaruh nyata negatif terhadap jumlah daun yakni konsentrasi tersebut dapat menurunkan jumlah daun.

\section{Luas Daun}

Tabel 2. Luas Daun pada Dua Bentuk Stek akibat Konsentrasi Auksin pada Umur 20, hst, 40 hst, dan 60 hst.

\begin{tabular}{|c|c|c|c|}
\hline \multirow{2}{*}{ Perlakuan } & \multicolumn{3}{|c|}{ Luas Daun pada Umur } \\
\hline & 20 hst & 40 hst & 60 hst \\
\hline Bentuk Pemotongan (B) & &.. $\mathrm{cm}^{2}$. & \\
\hline $\mathrm{b}_{1}$ : bentuk pemotongan miring & $1.39 \mathrm{a}$ & $17,33 \mathrm{a}$ & $36,33 \mathrm{a}$ \\
\hline $\mathrm{b}_{2}$ : bentuk pemotongan " $\mathrm{v} "$ & $1.61 \mathrm{a}$ & $17,94 \mathrm{a}$ & $41,33 \mathrm{a}$ \\
\hline Konsentrasi Auksin (A) & & & \\
\hline $\mathrm{a}_{0}: \quad 0 \mathrm{~g} \mathrm{~L}^{-1}$ & $4,50 \mathrm{a}$ & $17,17 \mathrm{~b}$ & $40,00 \mathrm{~b}$ \\
\hline $\mathrm{a}_{1}: 0.1 \mathrm{~g} \mathrm{~L}^{-1}$ & $10,00 \mathrm{c}$ & $24,83 \mathrm{c}$ & $50,17 \mathrm{~b}$ \\
\hline $\mathrm{a}_{2}: 0.2 \mathrm{~g} \mathrm{~L}^{-1}$ & $8,67 \mathrm{~b}$ & $18,00 \mathrm{~b}$ & $48,50 \mathrm{~b}$ \\
\hline $\mathrm{a}_{3}: 0.3 \mathrm{~g} \mathrm{~L}^{-1}$ & $12.00 \mathrm{c}$ & $27,17 \mathrm{c}$ & $66,67 \mathrm{c}$ \\
\hline $\mathrm{a}_{4}: 0.4 \mathrm{~g} \mathrm{~L}^{-1}$ & $4,00 \mathrm{a}$ & $10,33 \mathrm{a}$ & $15,50 \mathrm{a}$ \\
\hline $\mathrm{a}_{5}: 0.5 \mathrm{~g} \mathrm{~L}^{-1}$ & $2,00 \mathrm{a}$ & 8,33 a & $12,17 \mathrm{a}$ \\
\hline
\end{tabular}

Keterangan : Nilai rata-rata yang ditandai dengan huruf yang sama berarti berbeda tidak nyata menurut uji Jarak berganda Duncan taraf nyata $\%$.

Pada saat 20 hst, bentuk pemotongan stek yang miring dan bentuk $\mathrm{v}$ tidak berpengaruh nyata terhadap luas daun. Konsentrasi auksin $0,1 \mathrm{~g} \mathrm{~L}^{-1}, 0,2 \mathrm{~g}$ $\mathrm{L}^{-1}$, dan $0,3 \mathrm{~g} \mathrm{~L}^{-1}$ berpengaruh nyata terhadap luas daun yakni konsentrasi tersebut dapat meningkatkan luas daun. Namun, konsentrasi auksin $0,1 \mathrm{~g} \mathrm{~L}^{-1}$ dan $0,3 \mathrm{~g} \mathrm{~L}^{-1}$ lebih meningkatkan luas daun. Konsentrasi auksin $0,5 \mathrm{~g} \mathrm{~L}^{-1}$ dan $0,4 \mathrm{~g} \mathrm{~L}^{-1}$ tidak berpengaruh nyata terhadap luas daun atau sama dengan konsentrasi $0 \mathrm{~g} \mathrm{~L}^{-}$

Pada saat 40 hst, bentuk pemotongan stek yang miring dan bentuk v tidak berpengaruh nyata terhadap luas daun. Konsentrasi auksin $0,1 \mathrm{~g} \mathrm{~L}^{-1}$ dan 0,3 $\mathrm{g} \mathrm{L}^{-1}$ berpengaruh nyata positif terhadap luas daun yakni konsntrasi tersebut dapat meningkatkan luas daun. Konsentrasi auksin $0,5 \mathrm{~g} \mathrm{~L}^{-1}$ dan $0,4 \mathrm{~g} \mathrm{~L}^{-1}$ berpengaruh nyata negatif terhadap luas daun yakni konsentrasi tersebut dapat menurunkan luas daun. Konsentrasi auksin dan 0,2 $\mathrm{g} \mathrm{L}^{-}$ 1 tidak berpengaruh nyata terhadap luas daun atau sama dengan konsentrasi $0 \mathrm{~g} \mathrm{~L}$ 1.

Pada saat 60 hst, bentuk pemotongan stek yang miring dan bentuk $\mathrm{v}$ tidak berpengaruh nyata terhadap luas daun. Konsentrasi auksin $0,3 \quad \mathrm{~g} \mathrm{~L} \mathrm{~L}^{-1}$ berpengaruh nyata positif terhadap luas daun yakni konsentrasi tersebut dapat meningkatkan luas daun. Konsentrasi auksin $0,5 \mathrm{~g} \mathrm{~L}^{-1}$ dan $0,4 \mathrm{~g} \mathrm{~L}^{-1}$ berpengaruh nyata negatif terhadap luas daun yakni konsentrasi tersebut dapat menurunkan luas daun. Konsentrasi auksin $0,1 \mathrm{~g} \mathrm{~L}^{-1}$ dan $0,2 \mathrm{~g} \mathrm{~L}^{-1}$ tidak berpengaruh nyata terhadap luas daun atau sama dengan konsentrasi $0 \mathrm{~g} \mathrm{~L}^{-1}$. 


\section{Jumlah Cabang}

Tabel 3. Jumlah Cabang per Tanaman pada Dua Bentuk Stek akibat Konsentrasi Auksin pada Umur 20, hst, 40 hst, dan 60 hst

\begin{tabular}{|c|c|c|c|}
\hline \multirow{2}{*}{ Perlakuan } & \multicolumn{3}{|c|}{ Jumlah Cabang per Tanaman pada Umur } \\
\hline & 20 hst & 40 hst & 60 hst \\
\hline Bentuk Pemotongan (B) & \multicolumn{3}{|c|}{..................cabang.................. } \\
\hline $\mathrm{b}_{1}$ : bentuk pemotongan miring & 0,94 a & $1.53 \mathrm{a}$ & $1.66 \mathrm{a}$ \\
\hline $\mathrm{b}_{2}$ : bentuk pemotongan " $\mathrm{v} "$ & 0,99 a & $1.57 \mathrm{~b}$ & $1.74 \mathrm{a}$ \\
\hline \multicolumn{4}{|l|}{ Konsentrasi Auksin (A) } \\
\hline $\mathrm{a}_{0}: \quad 0 \mathrm{~g} \mathrm{~L}^{-1}$ & $0,88 \mathrm{ab}$ & $1,51 \mathrm{~b}$ & $1,76 \mathrm{~b}$ \\
\hline $\mathrm{a}_{1}: 0.1 \mathrm{~g} \mathrm{~L}^{-1}$ & $1,14 \mathrm{bc}$ & $2,04 \mathrm{c}$ & $2,16 \mathrm{bc}$ \\
\hline $\mathrm{a}_{2}: 0.2 \mathrm{~g} \mathrm{~L}^{-1}$ & $1,05 \mathrm{bc}$ & $1,91 \mathrm{bc}$ & $2,00 \mathrm{bc}$ \\
\hline $\mathrm{a}_{3}: 0.3 \mathrm{~g} \mathrm{~L}^{-1}$ & $1,28 \mathrm{c}$ & $2,08 \mathrm{c}$ & $2,40 \mathrm{c}$ \\
\hline $\mathrm{a}_{4}: 0.4 \mathrm{~g} \mathrm{~L}^{-1}$ & $0,71 \mathrm{a}$ & 0,88 a & 1,03 a \\
\hline a5 $: 0.5 \mathrm{~g} \mathrm{~L}^{-1}$ & 0,71 a & 0,88 a & 0,88 a \\
\hline
\end{tabular}

Keterangan : Nilai rata-rata yang ditandai dengan huruf yang sama berarti berbeda

tidak nyata menurut uji Jarak berganda Duncan taraf nyata 5\%

Pada saat 20 hst, bentuk pemotongan stek yang miring dan bentuk $\mathrm{v}$ tidak berpengaruh nyata terhadap jumlah cabang. Konsentrasi auksin 0,3 g $\mathrm{L}^{-1}$ berpengaruh nyata positif terhadap jumlah cabang yakni konsentrasi tersebut dapat meningkatkan jumlah cabang. Konsentrasi auksin 0,5 g L-1 dan 0,4 g L $\mathrm{L}^{-1}$ berpengaruh nyata negatif terhadap jumlah cabang yakni konsentrasi tersebut dapat menurunkan jumlah cabang. Konsentrasi auksin $0,1 \mathrm{~g} \mathrm{~L}^{-1}$, dan $0,2 \mathrm{~g} \mathrm{~L}^{-1}$ tidak berpengaruh nyata terhadap jumlah daun atau sama dengan konsentrasi $0 \mathrm{~g} \mathrm{~L}$ 1 .

Pada saat 40 hst, bentuk pemotongan stek yang miring tidak berpengaruh nyata terhadap jumlah cabang sedangkan bentuk pemotongan stek yang bentuk $\mathrm{v}$ berpengaruh nyata terhadap jumlah cabang yakni bentuk pemotongan stek bentuk $\mathrm{v}$ dapat meningkatkan jumlah cabang. Konsentrasi auksin $0,1 \mathrm{~g} \mathrm{~L}^{-1}$ dan $0,3 \mathrm{~g} \mathrm{~L}^{-1}$ berpengaruh nyata positif terhadap jumlah cabang yakni konsntrasi tersebut dapat meningkatkan jumlah cabang. Konsentrasi auksin 0,5 $\mathrm{g} \mathrm{L}^{-1}$ dan 0,4 $\mathrm{g} \mathrm{L}^{-1}$ berpengaruh nyata negatif terhadap luas daun yakni konsentrasi tersebut dapat menurunkan jumlah cabang. Konsentrasi auksin dan 0,2 $\mathrm{g} \mathrm{L}^{-1}$ tidak berpengaruh nyata terhadap jumlah cabang atau sama dengan konsentrasi $0 \mathrm{~g} \mathrm{~L}^{-1}$.

Pada saat 60 hst, bentuk pemotongan stek yang miring dan bentuk $\mathrm{V}$ tidak berpengaruh nyata terhadap jumlah cabang. Konsentrasi auksin 0,3 g $\mathrm{L}^{-1}$ berpengaruh nyata positif terhadap jumlah cabang yakni konsentrasi tersebut dapat meningkatkan jumlah cabang. Konsentrasi auksin 0,5 $\mathrm{g} \mathrm{L}^{-1}$ dan 0,4 $\mathrm{g} \mathrm{L}^{-1}$ berpengaruh nyata negatif terhadap jumlah cabang yakni konsentrasi tersebut dapat menurunkan jumlah cabang. Konsentrasi auksin $0,1 \mathrm{~g} \mathrm{~L}^{-1}$ dan $0,2 \mathrm{~g} \mathrm{~L}^{-1}$ tidak berpengaruh nyata terhadap jumlah cabang atau sama dengan konsentrasi $0 \mathrm{~g}$ $\mathrm{L}^{-1}$. 


\section{Volume Akar}

Tabel 4. Volume Akar per Tanaman pada Dua Bentuk Stek akibat Konsentrasi Auksin pada Umur 20, hst, 40 hst, dan 60 hst

\begin{tabular}{|c|c|c|c|}
\hline \multirow{2}{*}{ Perlakuan } & \multicolumn{3}{|c|}{ Volume Akar per Tanaman pada Umur } \\
\hline & 20 hst & 40 hst & 60 hst \\
\hline Bentuk Pemotongan (B) & & $\ldots \mathrm{cm}^{3} \ldots$ & \\
\hline $\mathrm{b}_{1}$ : bentuk pemotongan miring & $0.08 \mathrm{a}$ & $0.20 \mathrm{a}$ & $0.47 \mathrm{a}$ \\
\hline b2 : bentuk pemotongan "v" & $0.10 \mathrm{a}$ & $0.26 \mathrm{~b}$ & $0.51 \mathrm{a}$ \\
\hline \multicolumn{4}{|l|}{ Konsentrasi Auksin (A) } \\
\hline $\mathrm{a}_{0}: \quad 0 \mathrm{~g} \mathrm{~L}^{-1}$ & $0,07 \mathrm{ab}$ & $0,20 \mathrm{bc}$ & $0,40 \mathrm{~b}$ \\
\hline $\mathrm{a}_{1}: 0.1 \mathrm{~g} \mathrm{~L}^{-1}$ & $0,12 \mathrm{ab}$ & $0,32 \mathrm{~d}$ & $0,68 \mathrm{c}$ \\
\hline $\mathrm{a}_{2}: 0.2 \mathrm{~g} \mathrm{~L}^{-1}$ & $0,10 \mathrm{a} b$ & $0,28 \mathrm{~cd}$ & $0,68 \mathrm{c}$ \\
\hline $\mathrm{a}_{3}: 0.3 \mathrm{~g} \mathrm{~L}^{-1}$ & $0,15 \mathrm{~b}$ & $0,37 \mathrm{~d}$ & $0,92 \mathrm{~d}$ \\
\hline $\mathrm{a}_{4}: 0.4 \mathrm{~g} \mathrm{~L}^{-1}$ & $0,08 \mathrm{ab}$ & $0,12 \mathrm{ab}$ & $0,17 \mathrm{a}$ \\
\hline $\mathrm{a}_{5}: 0.5 \mathrm{~g} \mathrm{~L}^{-1}$ & $0.03 \mathrm{a}$ & 0,08 a & 0,10 a \\
\hline
\end{tabular}

Keterangan : Nilai rata-rata yang ditandai dengan huruf yang sama berarti berbeda tidak nyata menurut uji Jarak berganda Duncan taraf nyata 5\%

Pada saat 20 hst, bentuk pemotongan stek yang miring dan bentuk $\mathrm{v}$ tidak berpengaruh nyata terhadap volume akar. Konsentrasi auksin $0,1 \mathrm{~g} \mathrm{~L}^{-1}$, 0,2 $\mathrm{g} \mathrm{L}^{-1}, 0,3 \mathrm{~g} \mathrm{~L}^{-1}, 0,4 \mathrm{~g} \mathrm{~L}-1$, dan 0,5 $\mathrm{g} \mathrm{L}^{-1}$ tidak berpengaruh nyata terhadap volume akar atau sama dengan konsentrasi $0 \mathrm{~g} \mathrm{~L}^{-1}$.

Pada saat 40 hst, bentuk pemotongan stek yang miring tidak berpengaruh nyata terhadap volume akar sedangkan bentuk pemotongan stek yang bentuk $\mathrm{v}$ berpengaruh nyata terhadap volume akar yakni bentuk pemotongan stek bentuk v dapat meningkatkan volume akar. Konsentrasi auksin 0,1 g L-1 dan 0,3 $\mathrm{g} \mathrm{L}^{-1}$ berpengaruh nyata positif terhadap volume akar yakni konsentrasi tersebut dapat meningkatkan volume akar.

\section{Panjang Akar}

Tabel 5. Panjang Akar per Tanaman pada Dua Bentuk Stek akibat Konsentrasi Auksin pada Umur 20, hst, 40 hst, dan 60 hst

\begin{tabular}{|c|c|c|c|}
\hline \multirow{2}{*}{ Perlakuan } & \multicolumn{3}{|c|}{ Panjang Akar per Tanaman pada Umur } \\
\hline & 20 hst & 40 hst & 60 hst \\
\hline Bentuk Pemotongan (B) & \multicolumn{3}{|c|}{ } \\
\hline $\mathrm{b}_{1}$ : bentuk pemotongan miring & $3.18 \mathrm{a}$ & $4.86 \mathrm{a}$ & 7.19 a \\
\hline $\mathrm{b}_{2}:$ bentuk pemotongan " $\mathrm{v}$ " & $3.38 \mathrm{a}$ & $5.18 \mathrm{a}$ & $7.86 \mathrm{a}$ \\
\hline \multicolumn{4}{|l|}{ Konsentrasi Auksin (A) } \\
\hline $\mathrm{a}_{0}: \quad 0 \mathrm{~g} \mathrm{~L}^{-1}$ & $2,77 \mathrm{abc}$ & $5,20 \mathrm{bc}$ & $7,18 \mathrm{~b}$ \\
\hline $\mathrm{a}_{1}: 0.1 \mathrm{~g} \mathrm{~L}^{-1}$ & $4,92 \mathrm{~cd}$ & $6,35 \mathrm{~cd}$ & $10,13 \mathrm{c}$ \\
\hline $\mathrm{a}_{2}: 0.2 \mathrm{~g} \mathrm{~L}^{-1}$ & $3,83 \mathrm{bcd}$ & $5,67 \mathrm{~cd}$ & $9,92 \mathrm{bc}$ \\
\hline $\mathrm{a}_{3}: 0.3 \mathrm{~g} \mathrm{~L}^{-1}$ & $5,83 \mathrm{~d}$ & $7,42 \mathrm{~d}$ & $10,63 \mathrm{c}$ \\
\hline $\mathrm{a}_{4}: 0.4 \mathrm{~g} \mathrm{~L}^{-1}$ & $1,97 \mathrm{ab}$ & $3,50 \mathrm{ab}$ & 4,10 a \\
\hline $\mathrm{a}_{5}: 0.5 \mathrm{~g} \mathrm{~L}^{-1}$ & $0,67 \mathrm{a}$ & $2,00 \mathrm{a}$ & 3,17 a \\
\hline
\end{tabular}

Keterangan : Nilai rata-rata yang ditandai dengan huruf yang sama berarti berbeda tidak nyata menurut uji Jarak berganda Duncan taraf nyata $5 \%$
Konsentrasi auksin 0,5 $\mathrm{g} \mathrm{L}^{-1}$ berpengaruh nyata negatif yakni konsentrasi tersebut dapat menurunkan volume akar. Konsentrasi 0,2 g L ${ }^{-1}$ dan 0,4 $\mathrm{g} \mathrm{L}^{-1}$ tidak berpengaruh nyata terhadap volume akar atau sama dengan konsentrasi auksin $0 \mathrm{~g}$ $\mathrm{L}^{-1}$.

Pada saat 60 hst, bentuk pemotongan stek yang miring dan bentuk $\mathrm{V}$ tidak berpengaruh nyata terhadap volume akar Konsentrasi auksin 0,1 $\mathrm{g} \mathrm{L}^{-1}$, 0,2 $\mathrm{g} \mathrm{L}^{-1}$, dan $0,3 \mathrm{~g} \mathrm{~L}^{-1}$ berpengaruh nyata positif terhadap luas daun yakni konsentrasi tersebut dapat meningkatkan luas daun. Konsentrasi auksin $0,5 \mathrm{~g} \mathrm{~L}^{-1}$ dan $0,4 \mathrm{~g} \mathrm{~L}^{-1}$ berpengaruh nyata negatif terhadap luas daun yakni konsentrasi tersebut dapat menurunkan luas daun. 
Pada saat 20 hst, bentuk pemotongan stek yang miring dan bentuk $\mathrm{v}$ tidak berpengaruh nyata terhadap panjang akar. Konsentrasi auksin $0,3 \mathrm{~g} \mathrm{~L}^{-1}$ sangat berpengaruh nyata positif terhadap panjang akar yakni konsentrasi tersebut dapat meningkatkan panjang akar. Konsentrasi auksin 0,5 g $\mathrm{L}^{-1}$ berpengaruh nyata negatif terhadap panjang akar yakni konsentrasi tersebut dapat menurunkan panjang akar. 0,1 $\mathrm{g} \mathrm{L}^{-1}, 0,2 \mathrm{~g} \mathrm{~L}^{-1}$, dan 0,4 g $\mathrm{L}^{-1}$ tidak berpengaruh nyata terhadap panjang akar atau sama dengan konsentrasi $0 \mathrm{~g} \mathrm{~L}^{-1}$.

Pada saat 40 hst, bentuk pemotongan stek yang miring dan bentuk $\mathrm{v}$ tidak berpengaruh nyata terhadap panjang akar. Konsentrasi auksin $0,3 \mathrm{~g} \mathrm{~L}^{-1}$ sangat berpengaruh nyata positif terhadap panjang akar yakni konsentrasi tersebut dapat meningkatkan panjang akar.

\section{Jumlah Akar}

Tabel 6. Jumlah Akar per Tanaman pada Dua Bentuk Stek akibat Konsentrasi Auksin pada Umur 20, hst, 40 hst, dan 60 hst

\begin{tabular}{|c|c|c|c|}
\hline \multirow{2}{*}{ Perlakuan } & \multicolumn{3}{|c|}{ Jumlah Akar per Tanaman pada Umur } \\
\hline & 20 hst & 40 hst & 60 hst \\
\hline Bentuk Pemotongan (B) & \multicolumn{3}{|c|}{ f..............akar................ } \\
\hline $\begin{array}{l}\mathrm{b}_{1}: \text { bentuk pemotongan miring } \\
\mathrm{b}_{2}: \text { bentuk pemotongan " } \mathrm{v} \text { " }\end{array}$ & $\begin{array}{l}2.30 \mathrm{a} \\
2.43 \mathrm{a}\end{array}$ & $\begin{array}{l}3.12 \mathrm{a} \\
3.33 \mathrm{a}\end{array}$ & $\begin{array}{l}4.14 \mathrm{a} \\
4.19 \mathrm{a}\end{array}$ \\
\hline Konsentrasi Auksin (A) & & & \\
\hline $\mathrm{a}_{0}: 0 \mathrm{~g} \mathrm{~L}^{-1}$ & $1,86 \mathrm{ab}$ & $3,26 \mathrm{~b}$ & $4,00 \mathrm{~b}$ \\
\hline $\mathrm{a}_{1}: 0.1 \mathrm{~g} \mathrm{~L}^{-1}$ & $3,21 \mathrm{~cd}$ & $3,49 \mathrm{~b}$ & $4,77 \mathrm{c}$ \\
\hline $\mathrm{a}_{2}: 0.2 \mathrm{~g} \mathrm{~L}^{-1}$ & $2,54 \mathrm{bc}$ & $3,48 \mathrm{~b}$ & $4,55 \mathrm{bc}$ \\
\hline $\mathrm{a}_{3}: 0.3 \mathrm{~g} \mathrm{~L}^{-1}$ & $3,62 \mathrm{~d}$ & $4,72 \mathrm{c}$ & $5,84 \mathrm{~d}$ \\
\hline $\mathrm{a}_{4}: 0.4 \mathrm{~g} \mathrm{~L}^{-1}$ & $1,84 \mathrm{ab}$ & 2,46 a & 3,08 a \\
\hline $\mathrm{a}_{5}: 0.5 \mathrm{~g} \mathrm{~L}^{-1}$ & 1,14 a & 1,92 a & $2,74 \mathrm{a}$ \\
\hline
\end{tabular}

Keterangan : Nilai rata-rata yang ditandai dengan huruf yang sama berarti berbeda

tidak nyata menurut uji Jarak berganda Duncan taraf nyata $5 \%$

Pada saat 20 hst, bentuk pemotongan stek yang miring dan bentuk $\mathrm{V}$ tidak berpengaruh nyata terhadap jumlah akar. Konsentrasi auksin $0,1 \mathrm{~g} \mathrm{~L}^{-1}$ dan $0,3 \mathrm{~g} \mathrm{~L} \mathrm{~L}^{-1}$ berpengaruh nyata positif terhadap jumlah akar yakni kosentrasi tersebut dapat meningkatkan jumlah akar. Konsentrasi auksin 0,2 $\mathrm{g} \mathrm{L}^{-1}, 0,5 \mathrm{~g} \mathrm{~L}^{-1}$, dan $0,4 \mathrm{~g} \mathrm{\textrm {L } ^ { - 1 }}$, tidak berpengaruh nyata terhadap jumlah akar atau sama dengan konsentrasi auksin $0 \mathrm{~g} \mathrm{~L}^{-1}$.

Pada saat 40 hst, bentuk pemotongan stek yang miring dan bentuk $\mathrm{v}$ tidak berpengaruh nyata terhadap
Konsentrasi auksin 0,5 $\mathrm{g} \mathrm{L}^{-1}$ berpengaruh nyata negatif terhadap panjang akar yakni konsentrasi tersebut dapat menurunkan panjang akar. 0,1 $\mathrm{g} \mathrm{L}^{-1}, 0,2 \mathrm{~g} \mathrm{~L}^{-1}$, dan $0,4 \mathrm{~g}$ $\mathrm{L}^{-1}$ tidak berpengaruh nyata terhadap panjang akar atau sama dengan konsentrasi $0 \mathrm{~g} \mathrm{~L}^{-1}$.

Pada saat 60 hst, bentuk pemotongan stek yang miring dan bentuk $\mathrm{V}$ tidak berpengaruh nyata terhadap panjang akar. Konsentrasi auksin 0,2 $\mathrm{g} \mathrm{L}^{-1}$, dan $0,3 \mathrm{~g} \mathrm{~L}^{-1}$ berpengaruh nyata positif terhadap panjang akar yakni konsentrasi tersebut dapat meningkatkan panjang akar. Konesntrasi $0,5 \mathrm{~g} \mathrm{~L}^{-1}$ dan $0,4 \mathrm{~g} \mathrm{~L}^{-1}$ berpengaruh nyata negatif terhadap panjang akar yakni konsentrasi tersebut dapat menurunkan panjang akar. Konsentrasi auksin, 0,1 g $\mathrm{L}^{-1}$, tidak berpengaruh nyata terhadap panjang akar atau sama dengan konsentrasi $0 \mathrm{~g} \mathrm{~L} \mathrm{~L}^{-1}$

jumlah akar. Konsentrasi auksin $0,3 \mathrm{~g} \mathrm{~L}^{-1}$ berpengaruh nyata positif terhadap jumlah akar yakni konsentrasi tersebut dapat meningkatkan jumlah akar. Konsentrasi auksin $0,5 \mathrm{~g} \mathrm{~L}^{-1}$ dan $0,4 \mathrm{~g} \mathrm{~L}^{-1}$ berpengaruh nyata negatif terhadap jumlah akar yakni konsentrasi tersebut dapat menurunkan jumlah akar. Konsentrasi auksin $0,1 \mathrm{~g} \mathrm{~L}^{-1}$ dan $0,2 \mathrm{~g} \mathrm{~L}^{-1}$ tidak berpengaruh nyata terhadap jumlah akar atau sama dengan konsentrasi $0 \mathrm{~g} \mathrm{~L}^{-1}$

Pada saat 60 hst, bentuk pemotongan stek yang miring dan bentuk $\mathrm{v}$ tidak berpengaruh nyata terhadap 
jumlah akar. Konsentrasi auksin $0,2 \mathrm{~g} \mathrm{~L}^{-1}$, dan $0,3 \mathrm{~g} \mathrm{~L} \mathrm{~L}^{-1}$ berpengaruh nyata positif terhadap jumlah akar yakni konsentrasi tersebut dapat meningkatkan jumlah akar. Konesntrasi 0,5 g L L dan $0,4 \quad \mathrm{~g} \mathrm{~L} \mathrm{~L}^{-1}$ berpengaruh nyata negatif terhadap

\section{Bobot Kering}

Tabel 7. Bobot Kering per Tanaman pada Dua Bentuk Stek akibat Konsentrasi Auksin pada Umur 60 hst

\begin{tabular}{|c|c|}
\hline Perlakuan & $\begin{array}{l}\text { Bobot Kering per tanaman pada umur } \\
\qquad 60 \mathrm{hst}\end{array}$ \\
\hline Bentuk Pemotongan (B) & f..............gram................. \\
\hline $\mathrm{b}_{1}$ : bentuk pemotongan miring & $0.02 \mathrm{a}$ \\
\hline $\mathrm{b}_{2}$ : bentuk pemotongan " $\mathrm{v} "$ & $0.35 \mathrm{a}$ \\
\hline \multicolumn{2}{|l|}{ Konsentrasi Auksin (A) } \\
\hline $\mathrm{a}_{0}: \quad 0 \mathrm{~g} \mathrm{~L}^{-1}$ & $0,02 \mathrm{a}$ \\
\hline $\mathrm{a}_{1}: 0.1 \mathrm{~g} \mathrm{~L}^{-1}$ & $0,01 \mathrm{a}$ \\
\hline $\mathrm{a}_{2}: 0.2 \mathrm{~g} \mathrm{~L}^{-1}$ & $0,04 \mathrm{a}$ \\
\hline a3 : $0.3 \mathrm{~g} \mathrm{~L}^{-1}$ & $0,01 \mathrm{a}$ \\
\hline $\mathrm{a}_{4}: 0.4 \mathrm{~g} \mathrm{~L}^{-1}$ & $0,02 \mathrm{a}$ \\
\hline $\mathrm{a}_{5}: 0.5 \mathrm{~g} \mathrm{~L}^{-1}$ & $0.01 \mathrm{a}$ \\
\hline
\end{tabular}

Keterangan : Nilai rata-rata yang ditandai dengan huruf yang sama berarti berbeda

tidak nyata menurut uji Jarak berganda Duncan taraf nyata 5\%

Pada saat 60 hst, bentuk pemotongan stek yang miring dan bentuk $\mathrm{v}$ tidak berpengaruh nyata terhadap bobot kering. Konsentrasi auksin 0,1 $\mathrm{g} \mathrm{L}^{-1}, 0,2 \mathrm{~g}$ $\mathrm{L}^{-1}, 0,3 \mathrm{~g} \mathrm{~L}^{-1}, 0,4 \mathrm{~g} \mathrm{~L}^{-1}$, dan $0,4 \mathrm{~g} \mathrm{~L}^{-1}$ tidak berpengaruh nyata terhadap bobot kering atau sama dengan $0 \mathrm{~g} \mathrm{~L}^{-1}$.

Auksin merupakan senyawa atau zat kimia yang dalam konsentrasi rendah dapat merangsang, menghambat atau sebaliknya mengubah proses fisiologis dalam Pertumbuhan dan perkembangan tanaman (Gardner, 1991). Terutama pada bagian-bagian vegetatif dari tanaman, hal ini tergantung dari tiap-tiap jenis tanaman atau sifat-sifat dari masing-masing jenis tanaman. 68

Auksin merupakan senyawa dengan ciri-ciri mempunyai kemampuan dalam mendukung terjadinya perpanjangan sel dengan struktur kimia indole ring, banyaknya kandungan auksin di dalam tanaman sangat mempengaruhi pertumbuhan tanaman (Suprapto, 2014). Auksin sebagai salah satu zat pengatur tumbuh bagi tanaman mempunyai pengaruh terhadap : pengembangan sel, fototropisme, geotropime, apikal dominansi, pertumbuhan akar jumlah akar yakni konsentrasi tersebut dapat menurunkan jumlah akar. Konsentrasi auksin, 0,1 g $\mathrm{L}^{-1}$, tidak berpengaruh nyata terhadap jumlah akar atau sama dengan konsentrasi $0 \mathrm{~g} \mathrm{~L}^{-1}$. partenokarpi, absission, pembentukan kalus, dan respirasi. 96

Semakin banyak dan luas permukaan daun maka fotosintat yang dihasilkan cenderung semakin banyak. Keberadaan daun sangat penting pada stek pucuk dan dapat mempengaruhi keberahasilan tumbuh stek. Namun demikian luas daun yang disisakan pada stek pucuk juga harus diperhatikan, sebab apabila daun pada stek terlalu banyak (luas) maka laju transpirasi akan tinggi sehingga akan menyebabkan stek menjadi layu.

Berdasarkan analisis statistik simpangan model dengan menggunakan aplikasi stats versi 27 tidak terdapat model kuadratik yang sesuai. Maka dari itu, tidak dapat ditentukan konsentrasi auksin yang optimum. 


\section{SIMPULAN}

1. Tidak terdapat interaksi antara bentuk pemotongan stek bentuk $\mathrm{v}$ dan miring dengan konsentrasi auksin terhadap pertumbuhan tanaman kastuba yakni terhadap jumlah daun, luas daun, jumlah cabang, volume akar, panjang akar, jumlah akar, dan bobot kering. Bentuk pemotongan stek dengan bentuk $\mathrm{v}$ meningkatkan jumlah daun, jumlah cabang, dan volume akar pada umur 40 hst. Konsentrasi auksin 0,3 g $\mathrm{L}^{-1}$ memberikan hasil tertinggi pada aspek pertumbuhan luas daun, jumlah cabang, volume akar, dan jumlah akar.

2. Tidak terdapat model kuadratik yang sesuai sehingga konsentrasi auksin yang optimum tidak dapat ditentukan. Konsentrasi auksin $0,3 \quad \mathrm{~g} \quad \mathrm{~L}^{-1}$ memberikan hasil tertinggi pada aspek pertumbuhan jumlah akar.

\section{DAFTAR PUSTAKA}

Astuti, dan Agung Sugianto. 2008. Buku Pintar Tanaman Hias. Jakarta: AgroMedia Pustaka.

Chairur, Rozikin. 2016. Budidaya Tanaman Kastuba. http://www.caraberkebunku.com/ 2016/05/budidaya-bunga-kastubadengan-cara-stek.html.
Gardner FP, RB Pearce and RL Mitchell. 1991. Fisiologi Tanaman Budidaya. Jakarta: UI Press

Mashudi, Hamdan. 2015. Kemampuan Tumbuh Stek Pucuk Pulai Gading (Alstonia Scholaris (L.) R. Br.) Dari Beberapa Posisi Bahan Stek Dan Model Pemotongan Stek. Jurnal Penelitian Kehutanan Wallacea.(4) (1).

Olberg, M W., dan Lopez, R G. 2016. Growth And Development Of Poinsettia (Euphorbia Pulcherrima) Finished Under Reduced Air Temperature And Bench-Top Root-Zoneheating. Elsevier. (197204).

Purnamasari. 2014. Keuntungan dan Kerugian Stek. https://janahpurnamasari.com/20 14/08/22/perbanyakan-tanamansecara-vegetatif-dengan-carasetek/.

Ratna Dewi A, Intan. 2008. Peranan dan Fungsi Fitohormon bagi Pertumbuhan Tanaman. Bandung: Universitas Padjadjaran.

Salisbury, B. F. dan C. W. Ross. 1995. Fisiologi Tumbuhan Jilid 3. ITB, Bandung.

Suprapto, A. 2014. Zat Pengatur Tumbuh Penting Meningkatkan Mutu, 21(1), 81-90. 